\title{
Study of the Memory Effect of PCDD/F During the Combustion of Several Biomasses in A Moving Grate Boiler
}

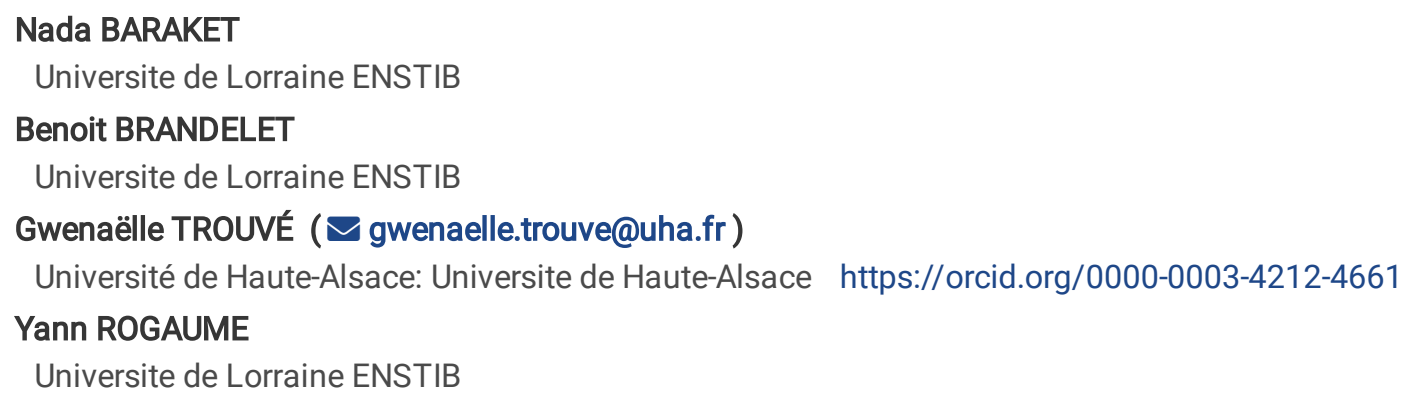

Keywords: PCDD/Fs Emission Combustion Biomasses Energy Memory effect

Posted Date: March 3rd, 2022

DOI: https://doi.org/10.21203/rs.3.rs-1317045/v1

License: @ (i) This work is licensed under a Creative Commons Attribution 4.0 International License. Read Full License 


\section{Abstract}

The objective of this work was to study the influence of temperature on the PCDD/Fs behavior stored in biomass ashes issued from an automatic pilot-scale wood boiler. A mixture of these ashes with a dioxin mass ratio dry based of $5.9 \mu \mathrm{gg} \cdot \mathrm{kg}^{-1}$ was used for thermal treatment at temperatures ranging between 200 and $500^{\circ} \mathrm{C}$. First tests were carried out in a macro thermogravimetric analysis instrument while couple of other tests were carried out in a quartz-lined crossed fixed-bed reactor. These treated ashes were afterwards analyzed and their dioxin mass ratio was determined. Results obtained from these both experiments are radically different: ashes treated in macro-TGA significantly contain more dioxins than the initial non-treated ashes while those from the reactor are extremely less concentrated. $91 \%$ of stored dioxins in the initial ashes were eliminated after $1 \mathrm{~h}$ at $400^{\circ} \mathrm{C}$ in crossed fixed-bed reactor. Macro-TGA experiments are a representation of what happens during the shut-down and cooling phase of the boiler, some areas reaching temperatures for which the PCDD/Fs formation is optimal. Without cleaning the boiler, a memory effect on further tests is observed.

\section{Introduction}

The necessity to reduce greenhouse emissions and to increase sustainable energy production has led to the promotion of renewable energy, such as biomass energy, which is the first renewable energy in the world: representing $9 \%$ of the world total primary energy supply, in 2018 (INTERNATIONAL ENERGY AGENCY 2020). In France, biomass energy is the main source of renewable energy: it represents more than $55 \%$ of final energy production in 2020 and therefore contributes significantly to reduce fossil fuels consumption (Ministry of ecological transition 2020). Wood combustion energy represents the majority of the biomass energy, with $35.8 \%$ (114 TWh) in primary renewable energy production in 2019 in France (Phan and Plouhinec 2020). Currently, wood combustion is used to produce heat and/or electricity in plants with capacities ranging from a few kWth to more than 500 MWth (Nussbaumer 2010).

Nevertheless, the use of this source of energy may accord the forest preservation policy and the quality of the ambient air standards. At the European level, directives 2004/107/EC and 2008/50/EC set sanitary standards which involves the obligation to monitor air quality, to inform the population about air quality and to implement action plans (The european parliament and the council of the european union 2004, 2008). Therefore, expanding the wood resource could be very challenging since not only natural wood is used. Indeed, wood waste, coated and treated wood and even wood mixed with other waste will be increasingly used (Cesprini et al. 2020).

The literature on the subject of wood waste combustion is well developed. The most used fuels are wood collected from waste disposal sites, industrial by-products and those emerging from construction and demolition activities. These types of fuels have very different compositions and could contain high levels of pollutants, which both promotes harmful emissions such as "dioxin emissions" (Martti 1996; Nussbaumer and Hasler 1997; Conesa et al. 2009; Weidemann et al. 2016; Moreno et al. 2016).

Dioxins refers to a large family of 210 members called "congeners". This family of compounds include 75 Polychlorinated Dibenzo-pDioxins (PCDD) congeners and 135 Polychlorinated DibenzoFurans (PCDF) congeners. These compounds are oxygenated heterocyclic aromatic molecules. They are considered among Persistent Organic Pollutants (POPs) (CITEPA / Format SECTEN 2017). Dioxins are very chemically stable, not biodegradable and persisting in the environment and in the living organisms in which they accumulate. The half-life of these pollutants is about seven years in the human body (CITEPA / Format SECTEN 2017). PCDD/Fs emissions are expressed as International Toxic factors or I-TEFs. On the basis on human and animal epidemiological data information, the International Agency for Research on Cancer (IARC) has classified dioxins and furans as "carcinogenic to humans" (CITEPA / Format SECTEN 2019). Seventeen of these isomers have been considered as extremely toxic, mutagenic and linked to the suppression of the human immune system (Alexander et al. 2017). Nowadays, these compounds are certainly among the most the most problematic as pollutants.

It is currently evident that PCDD/Fs can be formed under appropriate combustion conditions when carbon, hydrogen, oxygen and chlorine are present. Formation can occur in two ways: in vapor phase (i.e.: through a homogeneous reaction at a range of temperatures between 500 and $800^{\circ} \mathrm{C}$ ) or on solid surfaces such as soot or ash particles (i.e., through heterogeneous reactions at a range of temperatures between 200 and $400^{\circ} \mathrm{C}$ ) (Stanmore 2004). These both temperature ranges are crossed during the operating of a biomass combustion facility, along with the combustion test and while passing through the heat exchanger and the flue gas treatment system.

While many investigations have been performed to study the emissions of PCDD/Fs from municipal waste incinerators as well as hazardous waste incinerators (Fängmark et al. 1994; Huang and Buekens 1995; McKay 2002; Zhang et al. 2014, 2018; Block et al. 
2015; Li et al. 2019), there are fewer reports on dioxin emissions from wood combustions and especially from wood waste combustion and wood co-combustion with other biomass fuels (Schatowitz et al. 1994; Samaras et al. 2001; Lavric et al. 2004; Smołka-

Danielowska and Jabłońska 2021). These studies showed that the combustion of natural wood (oak, beech, pine) and uncoated chipboard (in stoves and in boilers) involve low dioxins emissions as long as the combustion is well controlled (adequate air supply and well-functioning of flue gas treatment devices in case of boilers). This is most likely due to the fact that these type of fuels do not contain high levels of pollutants such as chlorine, copper (Liao et al. 2016; Zhang et al. 2017).

It is common in biomass heating plants that the quality of the fuel change over time and within supplies. This can lead to variable and insufficiently controlled emission levels: for instance, after burning a waste biomass fuel with characteristics that allow the formation of dioxins and furans, the use of a clean biomass (natural forest chips) in the installation afterwards will lead to release these molecules again in the flue gases for a period. There is therefore a memory effect in the installation that needs to be understood. This phenomenon was already observed in waste treatment installations (Li et al. 2011). It consists of an enrichment of dioxins in the fly ashes during the cooling of the gases and the removal of dust, followed by a partial flight (Buekens and Huang 1998; Zhang et al. 2017).

Several studies have investigated the thermal treatment of fly ashes from municipal solid waste (MSW) incinerators, in order to understand the phenomena occurring during the cooling phase of flue gas in the plant. Abe et al. showed that dioxin concentration in flue gas resulting from fly ashes melting furnace, increased from $0.13 \mathrm{ng} / \mathrm{Nm}^{3}$ (at $12 \%$ of $\mathrm{O}_{2}$ ) at the inlet of the cooler to $0.54 \mathrm{ng} / \mathrm{Nm}^{3}$ at the outlet (Abe et al. 1996). Another study by Takasuka et al. showed that an electrostatic precipitator ashes collected from a municipal solid waste incinerator, can regenerate PCDD/Fs when heated in a rotary kiln at $300^{\circ} \mathrm{C}$ for 2 hours (Takasuka 1995). Another study conducted by Cunliffe et al. showed a significant increase of PCDD/Fs concentration in waste incineration fly ashes when treated in a bench scale reactor at a range of temperature between 200 and $400^{\circ} \mathrm{C}$ (Cunliffe and Williams 2009). The highest concentration was measured in fly ashes treated at $250^{\circ} \mathrm{C}(3478 \mu \mathrm{g} / \mathrm{kg}$ of ash) which is the equivalent of 12 times the initial amount of dioxins measured in the non-treated fly ashes (Cunliffe and Williams 2009). In this study, emissions were also analyzed; the highest level of PCDD/PCDFs emission $(11715 \mu \mathrm{g} / \mathrm{kg}$ of ash, which represents the equivalent of 42 times the initial amount of dioxins measured in the non-treated fly ash) occurred from waste incineration fly ashes heated at a temperature of $350^{\circ} \mathrm{C}$ in a bench scale reactor. High emissions in the exhaust gas were associated to a phenomenon of desorption of dioxins from the fly ashes to the gas phase (Cunliffe and Williams 2007a, 2009). Another study by Yokohama et al. has revealed that that PCDD/Fs (contained in ashes collected from a cooling system of a municipal waste incinerator) start to gasify at $350^{\circ} \mathrm{C}$ by thermal treatment performed using gas chromatograph (GC-12A) column oven (Yokohama et al. 2008). It was shown that dioxin gasification behavior in fly ashes depends on various conditions such as flow rate, ashes weight, heating period and temperature of treatment (Yokohama et al. 2008). Another study reported the behavior of simulated fly ashes when heated at $350^{\circ} \mathrm{C}$ under a flow of $\mathrm{N}_{2}$ and a flow of $\mathrm{N}_{2}$ containing $10 \%$ of $\mathrm{H}_{2}$. The results of this study showed that the hydrogen adding to the gas flow has a good inhibition effect on PCDD/Fs formation in ashes during heat treatment (Yang et al. 2015).

In this context, the present paper aims to study ashes behavior resulting from biomass combustion and to investigate if the same dioxins re-release phenomenon would act from this type of ashes. This was done by simulating what happens in the boiler and what ashes undergoes when being exposed to different temperature levels.

\section{Materials And Methods Presentation of the fuel}

In order to better understand the mechanisms of formation of dioxins, the properties of the studied fuel must be perfectly known. Table 1 gives proximate/ultimate characteristics of the fuel. The elemental analysis was carried out by external accredited (COFRAC) laboratory "SOCOR". 
Table 1

Proximate and ultimate analysis of used fuel

\begin{tabular}{|c|c|c|c|c|c|c|c|c|c|c|}
\hline Fuel & $\begin{array}{l}\text { Average ash (dry } \\
\text { basis } \\
\text { \%) }\end{array}$ & $\begin{array}{l}\text { Moisture (raw } \\
\text { basis } \\
\%)\end{array}$ & $\begin{array}{l}\mathrm{C} \\
(\%)\end{array}$ & $\begin{array}{l}\mathrm{H} \\
(\%)\end{array}$ & $\begin{array}{l}0^{a} \\
(\%)\end{array}$ & $\begin{array}{l}N \\
(\%)\end{array}$ & $\begin{array}{l}S \\
(\%)\end{array}$ & $\begin{array}{l}\mathrm{Cl} \\
(\%)\end{array}$ & $\begin{array}{l}\mathrm{Cu} \\
\left(\mathrm{mg} \cdot \mathrm{kg}^{-1}\right)\end{array}$ & $\begin{array}{l}\mathrm{LHV}^{\mathrm{b}} \\
\text { (dry basis } \\
\text { kJ.kg-1) }\end{array}$ \\
\hline $\begin{array}{l}\text { Biomass } \\
\text { mixture }\end{array}$ & 6.1 & 13.2 & 50.7 & 6.3 & 41.3 & 1.4 & 0.1 & 0.172 & 228 & 21100 \\
\hline
\end{tabular}

This fuel was a mixture of two different types of biomasses. It was prepared by mixing natural wood chips with a contaminated biomass (containing a higher level of chlorine compared to wood chips). The chosen ratio of this two components yielded a chlorine amount of $0.172 \%$ (mass ratio). It is known in the literature that chlorine has a crucial role in the formation of dioxins; as one of the main parameters (Stanmore 2004; Zhang et al. 2017). Therefore, it was analyzed within the elemental composition of fuel. Nitrogen was also included in this analysis since it can lead to nitrogen oxides $\left(\mathrm{NO}_{\mathrm{x}}\right)$ emissions. Moisture content of woody fuels commonly used in biomass boilers are significantly higher than the one used in this combustion test (13.2\%). In general, moisture content can range between 25 and $40 \%$ (on raw basis) for very wet fuels in thermal facilities for heat production and between 5 and $20 \%$ for less wet fuels (Rules of the Art Grenelle Environnement 2015). The average ash content varies also depending on the used fuel. A high ash content does not promote a good combustion and can lead to technical problems such as clinker formation, the clogging of the exchanger surfaces (Rules of the Art Grenelle Environnement 2015). The measurement of the ash content was carried out according to NF EN ISO 18122 (AFNOR 2015a, p. 18122) using a Nabertherm muffle furnace. The moisture measurement is performed according to NF EN ISO 18134-2 (AFNOR 2017, pp. 18134-2) and is repeated three times per sample. The calorific value measurements are performed on anhydrous samples. This analysis is carried out in accordance with the NF EN 14918 standard (AFNOR 2018, p. 14918) and using the 6100 Calorimeter from Parr.

The elemental analysis was conducted by a certified laboratory "SOCOR". Carbon, hydrogen and nitrogen were measured by a microanalyzer in accordance with the standard NF EN ISO 16948 (AFNOR 2015b, p. 16948).

Carbon, hydrogen, oxygen and nitrogen content varies and depends on the biomass type (Smołka-Danielowska and Jabłońska 2021).

Chlorine and Sulphur were measured using ion chromatography according to the internal method PA 334 . According to the bibliography, copper has an important role by acting as a catalyst during the formation of dioxins, whether in the homogeneous pathway (in the gas phase), heterogeneous pathway (via the precursor pathway by catalyzing the condensation and chlorination of aromatic compounds, on solid surfaces) or during the "De novo" synthesis (Huang and Buekens 1995; Stanmore 2004). Therefore, this metal was added to the list of elements to be analyzed. It was analyzed following the standard NF EN ISO 16968 (AFNOR 2015c, p. 16968).

\section{Presentation of the boiler}

A biomass combustion test was carried out in an automatic $200 \mathrm{~kW}$ wood boiler (about $50 \mathrm{~kg}$ per hour) with a moving grate firing (Fig. 1). The removal of particles present in the exhaust gas was carried out with a cyclone and a fabric filter. Gaseous emissions were also measured. Emissions were analyzed with a gas analyzers TESTO 350XL and PG 350 (HORIBA, KYOTO, JAPAN). The TESTO $350 \mathrm{XL}$ analyzes the composition of the flue gas $\left(\mathrm{O}_{2}, \mathrm{CO}, \mathrm{NO}_{x}, \mathrm{SO}_{\mathrm{x}}\right)$ by means of photochemical cells. $\mathrm{CO}_{2}$ was not directly measured, but calculated from the $\mathrm{O}_{2}$ value. While the second measuring device; the PG350 applied several quantification methods depending on the gases to be analyzed; paramagnetic detector for $\mathrm{O}_{2}$, detector based on the chemiluminescence principle for $\mathrm{NO}$ and non-dispersive infrared for $\mathrm{CO}, \mathrm{CO}_{2}$ and $\mathrm{SO}_{\mathrm{x}}$. In addition, all deposited ashes were collected separately at the end of the test and after the required cooling time. The combustion test was carried out for about eight hours of run in order to obtain a sufficient quantity of ashes.

Combustion test was carried out with primary and secondary air supplies optimized to maintain adequate $\mathrm{O}_{2}$ levels and to minimize $\mathrm{CO}$ emission. During combustion, the boiler was operated with a power of approximately $200 \mathrm{~kW}$. Main gaseous and particulate emissions are presented in Supplementary Materials in Table S1.

\section{Ash sampling protocol}


The collect ashes at different sampling points in a thermal facility during biomass combustion is not common in the published literature. The results often represent the analysis of total deposited ashes in the boiler (bottom ash) and the analysis of total collected ashes from the heat exchanger and flue gas treatment systems (e.g. electrostatic precipitator (ESP)) called fly ashes.

Figure 1 shows the seven sampling points in the thermal facility: combustion chamber, ash pan, combustion chamber door and surrounding walls, before the exchanger, mid-exchanger, cyclone, bag filter. The choice of the required number of sampling points was made according to the different temperature levels reached in each compartment, but also according to the possibilities of collecting sufficient quantities.

Ashes were collected using a brush and a vacuum pump. Before moving from a collecting point to another, the vacuum was cleaned and collected ashes were stored in a clean and dry storage container in order to be kept away from light and heat.

\section{Elementary analysis}

In combustion processes, transition metals have a major role in enhancing dioxins formation by catalyzing reactions (Huang and Buekens 1995; Stanmore 2004; Liao et al. 2016; Moreno et al. 2016). Therefore, the elemental analysis of ashes included other chemical elements (metals) with the classic ones (Carbon, Nitrogen and halogens) was performed and results given in Supplementary Materials in Table S2.

The highest carbon contents were measured in the cyclone and bag filter ashes (sampling points 6 and 7). These ashes and the ones collected from combustion chamber contains the highest sulfur and nitrogen contents. The chlorine contents are increasingly high as moving from the combustion chamber ashes to the gas treatment systems compartment; the highest content was measured in the bag filter which are extremely high with nearly $2.5 \mathrm{~kg}$ of chlorine per ton of dry burnt fuel. The lowest copper contents were measured in the exchanger (points 4 and 5). Overall, the most abundant chemical elements measured in collected ashes are chlorine, potassium, sodium and iron. The partitioning of mineral elements (transition metals, heavy metals and non-metals) in a combustion process was described in the literature. Their distribution between grate ashes, bottom ashes and fly ashes depends on the vapor pressure of these elements at the temperatures in the system that determines their volatility. Among the metals, certain such as $\mathrm{Cd}, \mathrm{Hg}, \mathrm{Pb}$ and $\mathrm{Zn}$ are the most volatile and are mainly found in the gases associated with fly ashes (Trouve and Delfosse 1997). Other metals such as Cu are distributed between the two types of ash (bottom ashes and fly ashes) depending on the presence of other non-metals such as $\mathrm{Cl}, \mathrm{O}$, and S (Trouve and Delfosse 1997). Another study investigating critical aspects of biomass ashes has presented some biomass combustions ashes. It was shown that bottom ashes have a distinct chemical composition from that of the fly ashes. Excluding $\mathrm{C}, \mathrm{H}$ and N, most elements of the biomass fuel are partially or completely remained in ashes (Freire et al. 2015).

\section{Dioxins and furans amounts}

Table S3 in Supplementary Materials shows PCDD/Fs amounts in collected ashes from each sampling point and their temperatures during the combustion test. The total amount of PCDD/Fs measured is the sum of the amounts measured in each type of ashes multiplied by its own collected mass. This total amount was $69000 \mathrm{ng}$ per $\mathrm{kg}$ of dry ashes. PCDD/Fs for each type of ashes expressed in $\mathrm{ng}$ per $\mathrm{kg}$ of dry ashes and in ng per ton of dry burnt fuel. PCDD/Fs ratios were also presented in the same table. Most of PCDD/Fs are found stored in the exchanger ashes (collecting point numbers 4 and 5 ) with a value of $84 \%$ of total PCDD/Fs. Starting from the exchanger, all collected ashes from the upstream of the combustion chamber (sampling point numbers 6 and 7 ) show high concentrations of dioxins. A total close to $90 \%$ of PCDD/Fs were measured in the exchanger, cyclone and the bag filter ashes (sampling point numbers 4,5,6 and 7, respectively). This phenomenon has already been observed in municipal solid waste treatment plants and reported since the 1990's. It consists in an enrichment of dioxins amounts in the fly ashes during the cooling of the gases and the removal of fly ashes within the treatment devices (Zhang et al. 2017, 2018). Thus, it can be assumed that the formation mechanisms during a biomass combustion could be similar to what has been observed in incineration plants.

During this combustion test, emission factor for dioxins was measured in three replicates in exhaust gas (collecting point number 8 on the Fig. 1), average was calculated according to the toxic equivalent systems I-TEQ WHO (1998) in $\mathrm{ng}$ per $\mathrm{Nm}^{3}$. The maximal value of emitted dioxins for ICPE (Installation classified for the protection of the environment) type 2910-B installations is 0.1 I-TEQ $\mathrm{ng}^{-\mathrm{Nm}^{-3}}$. The dioxins emission factor in the exhaust gas overshoot of 0.8 I-TEQ ng. $\mathrm{Nm}^{-3}$; which is 8 times higher than the allowed emission value.

\section{Experimental Mixture of Ashes (EMA)}


Three types of these collected ashes were selected to prepare a mixture of macroscopic composition that was treated afterwards in a macro-TGA and in a crossed fixed-bed reactor (FBR). The choice was made according to the dioxin contents measured in the collected ashes. Used ashes ratios and dioxin contents are reported in the following section. The mixture is now described as EMA for Experimental Mixture Ashes.

\section{Elementary analysis}

Table 2 shows the elemental composition of EMA which was calculated on the basis of the elemental compositions of different ashes from which EMA is composed. EMA is mostly high in chlorine, zinc, sodium and sulfur. Copper is also present in a smaller amount.

Table 2

\begin{tabular}{|ll|}
\hline \multicolumn{2}{|c|}{ EMA elemental composition } \\
\hline $\mathrm{C}^{1}$ & 768.0 \\
\hline $\mathrm{N}^{1}$ & 18.5 \\
$\mathrm{Cl}^{2}$ & 1570057 \\
\hline $\mathrm{S}^{2}$ & 210279 \\
\hline $\mathrm{Cu}^{2}$ & 4100 \\
\hline $\mathrm{Mn}^{2}$ & 12445 \\
\hline $\mathrm{Ni}^{2}$ & 186 \\
\hline $\mathrm{Pb}^{2}$ & 59695 \\
\hline $\mathrm{Zn}^{2}$ & 774843 \\
\hline $\mathrm{Na}^{2}$ & 279117 \\
\hline $\mathrm{K}^{2}$ & 1249872 \\
\hline $\mathrm{Fe}^{2}$ & 158725 \\
\hline 1 in g.ton & -1 \\
\hline 2 dry burnt fuel
\end{tabular}

The most abundant chemical elements measured in EMA are chlorine, potassium, sodium and zinc. Sulfur and sodium are also present but in less significant quantities.

\section{Dioxins and furans amounts}

EMA is a mixture of $10 \%$ of exchanger ashes (collect point numbers 4 and 5), $30 \%$ of cyclone ashes (collect point number 6 ) and $60 \%$ bag filter ashes (collect point number 7). These three types of ashes have the highest dioxins levels compared to other collected ashes. The mixture was prepared in such a way to have a significant dioxin level in order to increase the detection of the phenomena during their future thermal treatments at temperature levels corresponding to those of the Novo synthesis and the precursors pathway. To ensure a significant level of dioxins, the PCDD/Fs content in the EMA was calculated based on the PCDD/Fs content measured at the selected points of collection and reported to their masses in the mixture (Exchanger, cyclone and bag filter ashes). Values are shown in the Table 3. 
Table 3

PCDD/Fs amount of EMA

\begin{tabular}{|c|c|c|c|c|}
\hline Ash type & $\begin{array}{l}\text { Ash collecting } \\
\text { point }\end{array}$ & $\begin{array}{l}\text { Percentages } \\
(\%)\end{array}$ & $\begin{array}{l}\text { Ashes mass } \\
(\mathrm{kg})\end{array}$ & $\begin{array}{l}\mathrm{PCDD} / \mathrm{Fs} \text { in ashes (I-TEQ ng. } \mathrm{kg}^{-1} \text { of dry ashes (OMS TEF } \\
\text { 1998)) }\end{array}$ \\
\hline \multirow[t]{2}{*}{ Exchanger } & 4 & 5 & 0.1 & 32000 \\
\hline & 5 & 5 & 0.1 & 26000 \\
\hline Cyclone & 6 & 30 & 0.6 & 1300 \\
\hline Bag filter & 7 & 60 & 1.2 & 2600 \\
\hline EMA & Total & 100 & 2 & $4900^{a}$ \\
\hline
\end{tabular}

After thermal experiments in both macro-TGA and crossed fixed-bed reactor, samples were sent for dioxin analysis. An untreated ash sample (EMA) was also sent for analysis to determine the actual amount of dioxins (see Table 4).

\section{Macro-TG and crossed fixed bed reactors}

In order to identify possible release of dioxins stored in ashes or the formation of additional quantities of dioxins during a stop action of the thermal facility, a laboratory crossed fixed-bed reactor and a macro-TGA were dedicated to test the impact of different temperature levels on EMA.

In the first set of experiments, several tests were carried out with a macro TGA (Nabertherm) using relative important masses at different temperatures and reaction times as shown on Fig.. A sample of ashes was placed in a crucible, heated at a selected temperature of $200,250,300,350,400,450$ and $500^{\circ} \mathrm{C}$ for a varying period ranging (between 15 minutes and 2 hours). The airflow was in the range of 1.2 to $1.5 \mathrm{~m}^{3} / \mathrm{h}$ at $500^{\circ} \mathrm{C}$. Macro-TGA experiments are a representation of what happens when ashes are deposited in the boiler and fumes passes above it, in particular in the exchanger where temperatures are in the same chosen range (between 200 and $\left.500^{\circ} \mathrm{C}\right)$.

Ashes were initially dried in an oven for 48 hours at $105^{\circ} \mathrm{C}$ and left to cool in a desiccator for 1 hour. A mass close to $15 \mathrm{~g}$ of ash was weighed for each experiment. The ashes were then placed in a porcelain crucible and placed in the furnace of the macro-TGA for thermal treatment. At the end of the experiment, ashes were placed in the desiccator for 1 hour before weighting, which was carried out using a precision scale type XS205 Mettler Toledo (with an error of measurement of $0.01 \mathrm{mg}$ ). The weighting operation was performed each time using this same scale by the same person.

In the second set of experiments, a crossed fixed-bed reactor was used to carry out two tests at $400^{\circ} \mathrm{C}$, the first for one hour and the second for two hours (Fig). Deposited ashes are passed through by a very low speed air flow of $0.06 \mathrm{~m}^{3} / \mathrm{h}$. Experiments in this reactor are an illustration of what occurs during a combustion test, when fly ashes are trapped in the bag filter and crossed by the passing fumes.

As in macro-TGA experiments, ashes were initially dried in an oven for 48 hours at $103^{\circ} \mathrm{C}$ and left to cool in a desiccator for 1 hour. A mass close to $10 \mathrm{~g}$ of ashes were weighed and deposited on a quartz fiber filter fixed on a metal support which allows the air to flow through. After experiments, treated ashes were placed in a desiccator for 1 hour before weighting. Percentages of mass loss of all treated ashes were calculated for both experiments.

The emitted gases at the outlet of the reactor and the macro-TGA were not analyzed to measure dioxin contents, since both flow rates and experimental duration were too low to collect sufficient matter. The measurements of dioxins would be included in the error range.

In order to understand the effect of temperature on the dioxins stored in ashes and the effect of the heating period, ashes recovered after these tests were sent for dioxin analysis.

These two both experiments are fundamentally different. In macro-TGA, ashes will be overflown by the airflow which is the same that occurs in the boiler with ashes deposited in the exchanger, part of the combustion chamber and in the ash pan. In the fixed-bed reactor, ashes were crossed by the airflow which illustrate what occurs to ashes trapped in the bag filter. In the boiler, ashes are either passed 
through or overflown by air and gas flow, or both at the same time. The area where they are deposited and/or trapped, the type of the trap (bag filter, electrostatic filter (ESP), etc.) could determine the phenomenon that the ashes would undergo.

\section{Results And Discussions}

\section{Characterization of EMA after thermal treatment in macro-TGA}

Several experiments were carried out in a macro-TGA, while keeping the same temperature level, the treatment period was varied. Fig. 4 shows the mass loss at different temperatures and reaction times (expressed in mass percentage) for all treated ashes during macroTGA experiments. Residual carbon in treated ashes samples was measured in a muffle furnace at $850^{\circ} \mathrm{C}$ for three hours for only EMA and ashes treated in macro-TGA. Residual carbon shown in Fig. 4 are averages of three replications for each measurement. Values and standard deviations are given in Supplementary Materials in Table S4.

Results showed that increasing the reaction time and the temperature of treatment in macro-TGA promotes mass loss. The mass losses were progressively more important with increasing temperature; the most important mass loss were about $13 \%$ which was measured in ashes after a treatment at $500^{\circ} \mathrm{C}$ for $2 \mathrm{~h}$.

Residual carbon amounts were measured in treated ashes with the aim to determine a possible correlative link with dioxins formation since PCDD/Fs can be produced via heterogeneous reaction in flue gas via the De Novo mechanism (McKay 2002). Regards to deviation standards given in Supplementary materials in Table S4, before $350^{\circ} \mathrm{C}$, the residual carbon did not react. A significant decrease of residual carbon was observed from $350^{\circ} \mathrm{C}$ and above mainly for samples heated for a duration of two hours. This decrease is more important for samples treated at higher temperatures and for longer duration; residual carbon measured initially in EMA was $26.6 \%$ while the one measured in treated ashes for two hours was close to $17.8 \%$ and $12.5 \%$ in ashes for $350^{\circ} \mathrm{C}$ and $500^{\circ} \mathrm{C}$, respectively and for the same duration.

As reported in the literature by Kakuta et al., the amount of residual carbon decreased as the heating temperature increased while treating fly ashes above $400^{\circ} \mathrm{C}$ (Kakuta et al. 2005). Two reactions could take place. Several metals as copper in ashes could promote carbon oxidation and gasification at low temperatures (Stanmore 2004). The mass loss in ashes is still higher than the loss of residual carbon leading that if these two reactions could occur in ashes during the thermal treatment, other reactions could also take place.

\section{Dioxins and furans amounts}

Total amounts of PCDD/Fs in the initial and treated ashes in the macro-TGA are given in Table 4. The amount of dioxins measured in ashes treated at 200 and $250^{\circ} \mathrm{C}$ for 2 hours in macro-TGA is nearly the same as the one measured in the initial ashes considering the measurement error of $0.003 \mu \mathrm{g} \cdot \mathrm{kg}^{-1}$. Considering these error range, at temperature below $300^{\circ} \mathrm{C}$ dioxins amounts are in the same order of magnitude as the initial amount measured in EMA, which means that no change occurs at these temperatures. However, only with a relatively small increase of temperature of $50^{\circ} \mathrm{C}$, the amount of dioxins measured in ashes becomes slightly higher.

Table 4 shows that dioxins in ashes treated in macro-TGA significantly change depending on heating temperatures. The highest amounts were measured in ashes heated at 350,400 and $450^{\circ} \mathrm{C}: 44.1,71.3$ and 22.1 I-TEQ $\mu \mathrm{gg} \cdot \mathrm{kg}^{-1}$ of ashes, respectively, with a maximum at $400^{\circ} \mathrm{C}$ for $2 \mathrm{~h}$. 
Table 4

Dioxin amount in the initial non-treated ashes (EMA) and in treated ashes in macro-TGA and in crossed fixed-bed reactor (FBR) (I-TEQ $\mu \mathrm{g} . \mathrm{kg}^{-1}$ of ashes) and PCDD/Fs ratios at different temperatures

\begin{tabular}{|c|c|c|c|c|c|c|c|}
\hline & \multirow{2}{*}{$\begin{array}{l}\text { Period } \\
\text { (min) }\end{array}$} & \multirow{2}{*}{$\begin{array}{l}\text { Total PCDD/PCDFs (I-TEQ } \\
\mu \mathrm{g} \cdot \mathrm{kg}^{-1} \text { of ashes) }\end{array}$} & \multirow{2}{*}{$\begin{array}{l}\text { Temperature } \\
\left({ }^{\circ} \mathrm{C}\right)\end{array}$} & \multirow{2}{*}{$\begin{array}{l}\text { PCDD/PCDFs } \\
\text { ratios }\end{array}$} & \multicolumn{3}{|c|}{ Enrichment factor } \\
\hline & & & & & $\begin{array}{l}\mathrm{PCDD} / \mathrm{Fs} \\
\text { total }\end{array}$ & PCDDs & PCDFs \\
\hline \multirow[t]{10}{*}{$\begin{array}{l}\text { Macro- } \\
\text { TGA }\end{array}$} & EMA & 5.86 & $\begin{array}{l}\text { Initial non } \\
\text { treated-ash }\end{array}$ & 0.36 & - & - & - \\
\hline & 120 & 5.29 & 200 & 0.36 & 0.9 & 0.9 & 0.9 \\
\hline & & 4.99 & 250 & 0.39 & 0.9 & 0.9 & 0.9 \\
\hline & & 7.13 & 300 & 0.36 & 1.2 & 1.7 & 1.8 \\
\hline & & 44.10 & 350 & 0.22 & 7.5 & 10.1 & 16.4 \\
\hline & & 71.30 & 400 & 0.09 & 12.2 & 5.1 & 20.5 \\
\hline & & 22.10 & 450 & 0.11 & 3.8 & 1.8 & 6.1 \\
\hline & & 1.21 & 500 & 0.26 & 0.2 & 0.3 & 0.4 \\
\hline & 60 & 107.00 & 400 & 0.10 & 18.3 & 9.2 & 32.9 \\
\hline & & 2.80 & 500 & 0.17 & 0.5 & 0.3 & 0.7 \\
\hline \multirow[t]{2}{*}{ FBR } & 120 & 1.51 & 400 & 0.23 & 0.3 & 0.2 & 0.4 \\
\hline & 60 & 0.95 & 400 & 0.29 & 0.2 & 0.2 & 0.3 \\
\hline
\end{tabular}

Above $400^{\circ} \mathrm{C}$, the amount of dioxins measured in the treated ashes begins to decrease from $71.3 \mu \mathrm{gg} \cdot \mathrm{kg}^{-1}$ at $400^{\circ} \mathrm{C}$ to $22.1 \mu \mathrm{g} \cdot \mathrm{kg}^{-1}$ at $450^{\circ} \mathrm{C}$ for $2 \mathrm{~h}$. Moreover, ashes treated at $500^{\circ} \mathrm{C}$ (for 1 and for 2 hours) contained much lower dioxin amounts, even lower than the initial amount measured in non-treated ashes. For the same temperature level, ashes treated for a shorter period contained more dioxins (at $400^{\circ} \mathrm{C}$ and at $500^{\circ} \mathrm{C}$ ). Many mechanisms can occur and influence the PCDD/Fs amount in ashes during the thermal treatment, regardless the experimental used set-up (Cunliffe and Williams 2007b). Formation reactions can occur via De novo synthesis from residual carbon/char in presence of an oxygen source (Stanmore 2004) which is available from ashes in the flue gas in our case. Other phenomenons can also occur such as dechlorination, destruction and desorption, particularly at temperature above $400^{\circ} \mathrm{C}$. All simultaneously act varying the PCDD/Fs amounts (Cunliffe and Williams 2007b). In our case, the predominant phenomenon is the formation via de novo synthesis considering the high PCDD/Fs measured in ashes in macro-TGA experiments. As reported in a study carried by Kakuta et al. on several types of fly ashes, it showed that dioxin formation via De novo synthesis depended on gasification of carbon at $450^{\circ} \mathrm{C}$ regardless of the origin of carbon (Kakuta et al. 2007).

Enrichment factors of PCDD/Fs, were calculated in treated ashes compared to the initial amounts of these compounds in EMA. In the case of an enrichment factor less than 1, the amount of PCCD/Fs was decreased, as found in treated ashes at $200,250^{\circ} \mathrm{C}$ and $500^{\circ} \mathrm{C}$ for two hours and at $500^{\circ} \mathrm{C}$ for one hour. When the calculated enrichment factor is close to 1 , it can be concluded that PCDD/Fs levels are kept at the same order of magnitude than initial EMA, as in the case of treated ashes at $300^{\circ} \mathrm{C}$ for 2 hours. For all other treated ashes, the enrichment factors were significantly higher than 1 which means that PCDD/Fs amounts are largely increasing, especially in the case of treated ashes at $400^{\circ} \mathrm{C}$ for two hours (enrichment factor of about 12). Therefore, it can be confirmed that from $300^{\circ} \mathrm{C}$, treated ashes are enhanced with dioxins: PCDD/Fs amounts are increased by $22 \%, 653 \%, 1117 \%$ and $277 \%$ in ashes treated respectively at $300,350,400$ and $450^{\circ} \mathrm{C}$ for two hours.

Similar to what has been seen in literature, residual carbon can influence PCDD/Fs behavior during thermal treatment, but it is difficult to evaluate how carbon content affects the formation of PCDD/Fs since no direct correlation was found. In a study investigating several types of ashes resulting from biomass combustion, high levels of residual carbon (also named "unburned carbon") was found in the studied fly ashes compared to much lower levels in bottom ashes. These high levels of unburned carbon confirm that elevated amounts of PAHs and PCDD/Fs may have origin from the poor combustion performance (Freire et al. 2015). PCDD/Fs amounts were not exclusively related to the residual carbon and this due to the presence of other factors that can affect the formation of dioxins (Freire et al. 2015). 
Lundin et al. investigated the behavior of PCDD/Fs in ashes during thermal treatment in stainless steel reactor. Fly ashes were placed in a crucible in the middle of the reactor and heated to $300^{\circ} \mathrm{C}$ and $500^{\circ} \mathrm{C}$ in air. After the desired temperature of either $300^{\circ} \mathrm{C}$ or $500^{\circ} \mathrm{C}$ had been reached (after approximately 10 and $15 \mathrm{~min}$, respectively) ashes are maintained for a further $30 \mathrm{~min}$ in the reactor. The type of reactor used is similar to the one used in our experiments (macro-TGA). This study showed that a significant increase of PCDD/Fs amount was found in treated ashes at $300^{\circ} \mathrm{C}$. Conversely, PCDD/Fs amount measured in treated ashes at $500^{\circ} \mathrm{C}$ was much lower than both $300^{\circ} \mathrm{C}$ treated ashes and untreated ashes. The gas outlet was also sampled and analyzed. Results showed that PCDD/Fs was desorbed from ashes to the gas phase and concentrations in gas after treatment at $500^{\circ} \mathrm{C}$ were higher to the ones at $300^{\circ} \mathrm{C}(\mathrm{Lundin}$ et al. 2011). At $300^{\circ} \mathrm{C}$, the desorbed dioxins in the analyzed gas phases and the dioxins amounts in the treated ashes are proportional: the more dioxins the ash contains, the more dioxins are desorbed in the gas phase. This can lead to the conclusion, that during our thermal tests the increase of PCDD/Fs amounts in ashes after treatment at temperatures between 300 and $450^{\circ} \mathrm{C}$ should be associated with desorption toward the gaseous phase.

Based on macro-TGA dioxin results, if temperatures levels in the heat exchanger can be controlled to a maximum of $250^{\circ} \mathrm{C}$, the release of dioxins formed and stored in the ash can be significantly reduced. Avoiding the phenomenon of release within the exchanger ensures that it would be automatically avoided after in the emissions (exiting the bag filter).

The PCDD/PCDFs ratios in ashes treated at temperature between 200 and $300^{\circ} \mathrm{C}$ in macro-TGA are similar to the PCDD/PCDFs ratio of the initial non-treated ashes, which means that the total amounts of PCDDs and PCDFs remains unchanged. However, concerning the 350 to $450^{\circ} \mathrm{C}$ treated ashes, ratios were lower: the amounts of PCDFs are much higher than those of PCDDs. This was also seen in thermal treatment under post-combustion conditions in which treated ashes predominantly contained PCDFs at temperatures higher to $275^{\circ} \mathrm{C}$ (Cunliffe and Williams 2007a). While PCDDs result mainly from stable ortho-substituted chlorophenols that have survived from the primary combustion, PCDFs can form from several other reactions; such as the decomposition of carbonaceous compound which leads to phenoxyl radicals. These can combine in the gas phase to form dibenzo-furans. Additionally, chlorophenoxyl radicals can undergo heterogeneous condensation to form PCDF (Cunliffe and Williams 2007a). This may explain the different increase of PDDs and PCDFs.

\section{$P C D D / F s$ congeners in treated ashes}

Table 5 shows PCDDs congeners distribution in ashes treated at different temperatures for one and two hours. The distribution of PCDFs congeners is shown in Table 6. Congeners amounts are given in ng per kg of treated ashes. Quantification limits of each PCDDs and PCDFs congeners are given in Supplementary Materials in Table S5.

Table 5

PCDDs congeners amounts in EMA and in treated ashes in macro-TGA and fixed-bed reactor at different temperatures for 2 hours (table on the left) and for 1 hour (table on the right) ( $\mu \mathrm{g}$ per $\mathrm{kg}$ of ashes)

2 hours of treatment

1 hour of treatment

EMA

Macro TG

FBR Macro TG

FBR

Temperature

\begin{tabular}{|c|c|c|c|c|c|c|c|c|c|c|c|c|}
\hline PCDDs & 200 & 250 & 300 & 350 & 400 & 450 & 500 & 400 & 500 & 400 & 400 & \\
\hline 2,3,7,8-TeCDD & 0.686 & 0.608 & 0.607 & 1.410 & 7.570 & 2.560 & 0.143 & 0.220 & 0.461 & 5.410 & 0.131 & 0.816 \\
\hline 1,2,3,7,8-PeCDD & 1.750 & 1.760 & 2.140 & 7.080 & 12.600 & 4.530 & 0.296 & 0.521 & 0.793 & 19.000 & 0.288 & 1.930 \\
\hline $\begin{array}{l}1,2,3,4,7,8- \\
\text { HxCDD }\end{array}$ & 0.614 & 0.607 & 1.270 & 7.660 & 3.340 & 1.230 & 0.0970 & 0.159 & 0.188 & 8.230 & 0.123 & 0.673 \\
\hline $\begin{array}{l}1,2,3,6,7,8- \\
\text { HxCDD }\end{array}$ & 0.715 & 0.722 & 1.260 & 6.150 & 3.660 & 1.390 & 0.146 & 0.150 & 0.210 & 7.300 & 0.114 & 0.762 \\
\hline $\begin{array}{l}1,2,3,7,8,9- \\
\mathrm{HxCDD}\end{array}$ & 1.000 & 0.987 & 1.880 & 8.600 & 5.400 & 2.080 & 0.371 & 0.224 & 0.306 & 11.100 & 0.180 & 1.110 \\
\hline $\begin{array}{l}\text { 1,2,3,4,6,7,8- } \\
\text { HpCDD }\end{array}$ & 2.660 & 2.850 & 7.100 & 43.500 & 12.200 & 3.920 & 0.647 & 0.538 & 0.495 & 30.700 & 0.534 & 2.960 \\
\hline OCDD & 2.210 & 2.430 & 4.320 & 33.400 & 9.220 & 3.420 & 1.190 & 0.630 & 0.757 & 16.300 & 0.974 & 2.410 \\
\hline
\end{tabular}

Page 10/19 
Table 6 PCDFs congeners amounts in EMA and in treated ashes in macro-TGA and fixed-bed reactor at different temperatures for 2 hours (table on the left) and for 1 hour (table on the right) ( $\mu \mathrm{g}$ per $\mathrm{kg}$ of ashes)

\begin{tabular}{|c|c|c|c|c|c|c|c|c|c|c|c|c|}
\hline \multirow{2}{*}{\multicolumn{8}{|c|}{$\begin{array}{l}2 \text { hours of treatment } \\
\text { Macro TG }\end{array}$}} & \multicolumn{4}{|c|}{1 hour of treatment } & \multirow[t]{3}{*}{ EMA } \\
\hline & & & & & & & & \multirow[t]{2}{*}{ FBR } & \multicolumn{2}{|c|}{ Macro TG } & \multirow[t]{2}{*}{ FBR } & \\
\hline & Tempe & ature & & & & & & & & & & \\
\hline PCDFs & 200 & 250 & 300 & 350 & 400 & 450 & 500 & 400 & 500 & 400 & 400 & \\
\hline $\begin{array}{l}\text { 2,3,7,8- } \\
\text { TeCDF }\end{array}$ & 4.170 & 3.680 & 3.810 & 14.300 & 78.100 & 22.800 & 1.190 & 1.200 & 2.940 & 70.900 & 0.675 & 4.740 \\
\hline $\begin{array}{l}\text { 1,2,3,7,8- } \\
\text { PeCDF }\end{array}$ & 5.540 & 4.940 & 5.310 & 24.900 & 148.000 & 40.200 & 1.750 & 1.730 & 4.100 & 145.000 & 1.050 & 6.100 \\
\hline $\begin{array}{l}2,3,4,7,8- \\
\text { PeCDF }\end{array}$ & 3.810 & 3.390 & 5.310 & 41.600 & 59.800 & 16.300 & 0.806 & 0.775 & 1.610 & 99.200 & 0.481 & 4.100 \\
\hline $\begin{array}{l}1,2,3,4,7,8- \\
\text { HxCDF }\end{array}$ & 2.950 & 2.760 & 4.470 & 45.800 & 68.000 & 21.300 & 1.110 & 1.060 & 1.990 & 130.000 & 0.774 & 3.250 \\
\hline $\begin{array}{l}1,2,3,6,7,8- \\
\mathrm{HxCDF}\end{array}$ & 3.420 & 3.190 & 4.880 & 53.700 & 83.900 & 26.400 & 1.150 & 1.180 & 2.340 & 146.000 & 0.879 & 3.750 \\
\hline $\begin{array}{l}\text { 1,2,3,7,8,9- } \\
\text { HxCDF }\end{array}$ & 0.218 & 0.231 & 0.721 & 4.320 & 2.770 & 0.922 & 0.070 & 0.091 & 0.140 & 6.750 & 0.058 & 0.206 \\
\hline $\begin{array}{l}2,3,4,6,7,8- \\
\text { HxCDF }\end{array}$ & 1.670 & 1.710 & 5.850 & 59.300 & 28.300 & 8.620 & 0.504 & 0.442 & 0.794 & 69.700 & 0.386 & 1.730 \\
\hline $\begin{array}{l}1,2,3,4,6,7,8- \\
\text { HрCDF }\end{array}$ & 3.430 & 3.520 & 10.900 & 160.000 & 116.000 & 36.900 & 3.320 & 2.940 & 4.270 & 256.000 & 2.690 & 3.730 \\
\hline $\begin{array}{l}1,2,3,4,7,8,9- \\
\text { НрCDF }\end{array}$ & 0.595 & 0.613 & 2.970 & 29.900 & 6.730 & 1.580 & 0.158 & 0.271 & 0.242 & 19.900 & 0.241 & 0.646 \\
\hline OcCDF & 1.080 & 1.250 & 7.330 & 49.200 & 9.900 & 3.660 & 0.947 & 0.939 & 0.944 & 24.500 & 0.981 & 1.150 \\
\hline
\end{tabular}

The initial non-treated ash EMA, showed a PCDDs congener distribution mainly composes of the most chlorinate congeners (octa, hepta and penta-chlorinated). The same distribution was reported in Cunliffe and al. in the original used fly ashes obtained from an operational municipal solid waste incinerator of a moving grate design (Cunliffe and Williams 2009).

PCDFs congener distribution in non-treated EMA showed less chlorinated congeners (tetra, penta and hexa-chlorinated). This is similar to what has been shown in the analysis of several types of ashes taken from a waste incineration plant (not thermally treated); the amount of PCDFs is higher than that of PCDDs and the most chlorinated congeners are the most abundant ones (Cunliffe and Williams 2006).

In our analyses of treated ashes in the macro-TGA, both PCDDs and PCDFs families showed an increase of all congeners amounts in treated ash between 350 and $450^{\circ} \mathrm{C}$. Each congener was impacted by an enrichment in this temperature range and it was found that the most abundant PCDD congeners are the most chlorinated ones: octa-CDD and hepta-CDD and the most abundant PCDF congeners are hepta-CDF, hexa-CDF, tetra-CDF and penta-CDF. Mono-, di- and tri-chlorinated congeners were not included in the analysis. It was shown in literature that when thermally treated, the less chlorinated PCDFs in ashes were degraded to a greater extent than the more chlorinated PCDFs and the hepta and octa chlorinated PCDFs increased in concentration. This was explained by the fact that dechlorination of molecules with few chlorine atoms is faster than that of highly chlorinated PCDFs. It was also shown that dechlorination seemed to be greater for PCDFs than for PCDDs (Lundin et al. 2011).

\section{Characterization of EMA treated in crossed fixed-bed reactor}

After treatment in the crossed fixed-bed reactor at $400^{\circ} \mathrm{C}$, measured mass losses were about $12 \%$ for both ashes treated for one and two hours. Residual carbon measurement was not performed for theses ashes. 
Table 4 shows the total amount of PCDD/Fs in the initial ashes and in treated ashes in crossed fixed-bed reactor.

This table shows a significant decrease in the amount of dioxins at least of $75 \%$ compared to initial non-treated ashes (EMA). After treatment in a crossed fixed-bed reactor, the initial total amount of dioxins (in $\mu \mathrm{g}$ ) is divided by at least a factor of 7 . Enrichment factor were lower than 1 in both experiments at $400^{\circ} \mathrm{C}$ for $1 \mathrm{~h}$ and $2 \mathrm{~h}$ in the crossed fixed-bed reactor. They are quite constant in the range $0.2-$ 0.4 for both experiments.

In a similar study by Lundin et al., ashes treated at $500^{\circ} \mathrm{C}$ in an experimental set-up under a flue of air resulted in a decrease of the total PCDD/Fs amount in ashes with a reduction minimum of $75 \%$ observed but leaded to high PCDD/Fs concentrations in the gas phase (Lundin et al. 2011). These results from Lundin et al. confirm ours results meaning that under a flue crossed of air, the oxygen may diffuse in the ash bed in order to induce oxidative reactions/and or desorption of these molecules in the gas phase at temperatures above $450^{\circ} \mathrm{C}$. In addition, at temperatures ranging between $300^{\circ} \mathrm{C}$ and $400^{\circ} \mathrm{C}$ and in absence of oxygen, PCDD/Fs amounts progressively declined in ashes allowing the desorption of PCDD/Fs in the gas phase (Cunliffe and Williams 2006, 2007a).

The same result was shown in a study with fly ashes recovered from waste incineration, in which the amount of dioxins decreased significantly after being treated in quartz-lined crossed fixed-bed reactor (similar to the one used in our experiments) at 325, 350 and $400^{\circ} \mathrm{C}$ (Cunliffe and Williams 2007a). However, these experiments were carried out under simulated flue gas and for 4 days. It was shown in the same study that a considerable desorption of PCDD/Fs from fly ashes is observed at $275^{\circ} \mathrm{C}$ and above with a maximum at $350^{\circ} \mathrm{C}$ (Cunliffe and Williams 2007a).

According to the same study conducted by Cunliffe et al., from $325^{\circ} \mathrm{C}$ and above, the amount of desorbed dioxins is strongly increased, whereas the amount of remaining dioxins in ashes is strongly decreased (compared to original ashes and compared to treated ashes at lower temperatures).

The PCDD/PCDFs ratios calculated in the crossed fixed-bed reactor ashes are similar to the ratio calculated in the initial non-treated ashes, even though a remarkable decrease of the total dioxin amount was observed in these treated ashes. The PCDFs congeners were predominant in the untreated ashes (EMA) and also exceeded PCDDs congeners in the treated ashes. A study showed that PCDDs congeners decreases more markedly than did the PCDFs congeners. It also proved that the families behavior mainly depends on ashes composition and that their concentration after treatment vary uniformly: if PCDFs is predominant for example, it will be predominant in the treated ashes (Lundin et al. 2011). Based on the bibliography, it can conclude that the decrease of dioxins observed in the treated ashes is due mainly to a phenomenon of desorption of these molecules from solid phase to the gas phase.

$P C D D / F s$ congeners in treated ashes

Table 5 and and Table 6 provide the PCDDs and PCDFs congeners distribution in treated ashes in the crossed fixed-bed reactor.

As found in the macro-TGA treated ashes, the most abundant PCDDs congeners are the most chlorinated ones: octa-CDD and heptaCDD while, the most abundant PCDF congeners are hepta-CDF, tetra-CDF and penta-CDF whatever the duration time. The same result was found in a study conducted by Cunliffe et al. in treated fly ashes in a quartz lined reactor (Cunliffe and Williams 2007a).

The total PCDDs congeners measured in ashes after treatment was about $22 \%$ of the initial PCDDs in EMA. While, the total PCDFs congeners was about $28 \%$ in ashes treated for one hour and $36 \%$ in ashes treated for two hours. In a similar reactor as the one used in our experiment, ashes treated under a mixture of $8.8 \% \mathrm{O}_{2} / 92.2 \% \mathrm{~N}_{2}$ contained $1.4 \%$ of the total initial PCDDs content in the original non treated ashes and $10.7 \%$ of the total PCDFs content, after 50 min of heating at $398^{\circ} \mathrm{C}$ (Addink et al. 1995). Considering that although the used reactor and the temperature treatment level are similar in the study of Addink et al., the operating conditions (gas flowrate, the treatment duration and the ash mass) are different. If the quantity of ashes initially used $(2 \mathrm{~g})$ and the total gas flowrate $\left(6.6410^{-3}\right.$ $\mathrm{m}^{3} \cdot \mathrm{h}^{-1}$ ) were lower than in our experiment, the ratio mass/flowrate is in the same order of magnitude than in our experiment being 300 and 250 , respectively meaning that both experiments are quite similar and could be compared. As our this study, it can be seen that the PCDDs content reduction is more significant than the PCDFs content after a treatment at $400^{\circ} \mathrm{C}$ especially for two hours.

\section{Comparison of EMA characterization from macro-TGA results and crossed fixed-bed reactor}

The Fig. 5 allows the comparison of both experiments. 
The calculated percentages of mass loss were greater in ashes treated in crossed fixed-bed reactor tests than those treated in the macro-TGA. These differences are related to the characteristics of each device and their specific phenomena: in the crossed fixed-bed reactor, the air is directly in contact with ashes and can more easily oxidize the carbonaceous compounds present (soot carbon, organic compounds). In contrast, in macro-TGA, the air circulating in the kiln flows over the superficial layers of ashes but not directly through it.

Table 4 shows the quantities of dioxins measured in ashes treated in the crossed fixed-bed reactor and in macro-TGA, at the same temperature level $\left(400^{\circ} \mathrm{C}\right)$ and for the same period of thermal treatment. Results shows that dioxins amounts in crossed fixed-bed reactor ashes are much lower than those treated in the macro-TGA. If an enrichment of PCDD/Fs is observed on ashes in macro-TGA, the opposite is true in the fixed bed reactor.

In both experiments (macro-TGA and crossed fixed-bed reactor), several phenomena on dioxins can simultaneously occur, such as their oxidation with oxygen from the air, or a catalytic oxidation reaction, or their destruction by the temperature or desorption into the flue gas stream. All these different phenomenon act to change PCDD/Fs levels and occur simultaneously (Cunliffe and Williams 2007b). Dioxins can also be directly destroyed only by the effect of temperature or by oxidation, although this cannot be the dominating phenomenon (in both experiments) since these compounds are stable up to $800^{\circ} \mathrm{C}$ and their destruction is only total above $1300^{\circ} \mathrm{C}$ (Alexander et al. 2017). In addition, dioxin formation reactions can also occur alongside other reactions, since the chosen temperature range is adequate for formation, specifically via heterogonous reactions. Hence, the competition between the different phenomena and the different predominance lead to these different results obtained from both experiments: macro-TGA and crossed fixed-bed reactor.

In one hand, some studies showed that degradation of PCDD/Fs in closed systems (glass ampules) and under a gas flow is possible in an oxidative atmosphere (Hagenmaler et al. 1987; Lundin and Marklund 2005). Degradation can occur either via dechlorination/hydrogenation reactions or via oxidation reactions. In the other hand, other studies showed that when the outlet gas phase is analyzed, high PCDD/Fs concentrations are found after ashes heat treatment (Cunliffe and Williams 2007b, a; Lundin et al. 2011). Compering our results to heat treatment carried out in similar set-ups, it can conclude that changes observed in PCDD/Fs levels were mainly associated to the desorption of these molecules from the solid phase to the gas phase. Although degradation may occur, it is not the dominant phenomenon.

Based on results shown in Table 5 and Table 6, it can be seen that in both macro-TGA and crossed fixed-bed reactor, the initial PCDFs distribution of EMA changed: most chlorinated PCDFs congeners were significantly more abundant. While, there were no remarkable changes in the distribution of PCDDs congeners, even in treated ashes at $500^{\circ} \mathrm{C}$ with lower PCDDs amounts. According to literature this can be related to the fact that dechlorination of molecules with few chlorine atoms is faster compared to highly chlorinated ones (Lundin et al. 2011). In addition, it can confirm that dechlorination is more important for PCDFs than PCDDs congeners.

\section{Conclusion}

Collected ashes from biomass combustion test were heated in macro-TGA for $1 \mathrm{~h}$ and $2 \mathrm{~h}$ at different temperatures and in crossed fixedbed reactor at $400^{\circ} \mathrm{C}$ for 1 and 2 hours.

The macro-TGA results have shown that there is an increase in PCDD/Fs amounts measured in the treated ashes in particular in a range of temperatures between 350 and $400^{\circ} \mathrm{C}$. Dioxins amounts were 18 and 12 times higher in treated ashes at $400^{\circ} \mathrm{C}$ for 1 hour and 2 hours, respectively, compared to the initial amount measured in the non-treated ash. The increase of dioxins amounts in the treated ashes in macro-TGA would explain why the formation of dioxins persists over time, particularly during the cooling phases of the installation and consequently why a memory effect could be observed, if the installation is not cleaned of all solid residues from the previous test to the next one. The increase of dioxin amounts in treated ashes can also be combined and followed by a release of dioxins in the vapor phase. Since these macro-TGA experiments illustrate the ash cooling process within the boiler and especially in the exchanger, based on these results, at the boiler scale, in order to reduce and/or avoid the phenomenon of release in the exchanger, the temperature should be well controlled to a maximum of $250^{\circ} \mathrm{C}$. Avoiding this phenomenon within the exchanger may ensure that it would be automatically avoided in the exhaust gas.

In contrast, the heat treatment tests in crossed fixed-bed reactor did not show the same results. PCDD/Fs measured in ashes treated in this reactor were significantly lower than in initial non-treated ashes and in macro-TGA treated ash: $91 \%$ of the dioxins are removed/eliminated after $1 \mathrm{~h}$ at $400^{\circ} \mathrm{C}$. At the same temperature, a 2 hours heating treatment can lead to a reduction of $85 \%$ of the initial amount of dioxins. Based on similar experiments in literature, analyzed outlet gas phase showed high PCDD/Fs concentration.

Page 13/19 
As seen in the crossed fixed-bed reactor, dioxins stored in ashes are eliminated at $400^{\circ} \mathrm{C}$. However, the operating temperature of the bag filter range is between $110^{\circ} \mathrm{C}$ and $180^{\circ} \mathrm{C}$, consequently, it would not be possible to raise temperature to $400^{\circ} \mathrm{C}$ to ensure dioxins removing. The optimized solution to drastically reduce emissions of PCDD/Fs in the exhaust is to trap and evacuate the flying particles in order to avoid their emission and their storage in an area with a level of temperature allowing a desorption of dioxins.

\section{Declarations}

\section{Acknowledgments}

Authors thank the French National Agency for Ecological Transition for their financial support.

\section{Ethical Approval}

Authors attest that this work was not submitted elsewhere in another journal. There is not conflict of interest between them.

\section{Consent to Participate}

Not applicable: all participants of this project are authors.

\section{Authors Contributions}

Nada BARAKET: Experimentation, Format analysis, Writing

Benoît BRANDELET: Conceptualization, Methodology, Experimentation, Validation

Gwenaëlle TROUVÉ: Format analysis, Validation, Writing- Original draft, Review and Editing, Visualization

Yann ROGAUME: Supervision, Project administration, Funding acquisition, Resources

\section{Funding}

LERMAB is supported by a grant overseen by the French National Research Agency (ANR) as part of the "Investissementsd'Avenir" program (ANR-11-LABX-0002-01. Laboratory of Excellence ARBRE) and is part of ICEEL (Institut Carnot pour l'Energie et l'Environnement en Lorraine).

\section{Competing Interests}

The authors declare that they have no known competing financial interests or personal relationships that could have appeared to influence the work reported in this paper.

\section{Availability of data and materials}

Not applicable

\section{References}

1. Abe S, Kambayashi F, Okada M (1996) Ash melting treatment by rotating type surface melting furnace. Waste Manag 16:431-443. https://doi.org/10.1016/S0956-053X(96)00102-X

2. Addink R, Govers HAJ, Olie K (1995) Desorption behaviour of polychlorinated dibenzo-p-dioxins/dibenzofurans on a packed fly ash bed. Chemosphere 31:3945-3950. https://doi.org/10.1016/0045-6535(95)00266-B

3. AFNOR (2015a) Solid biofuels - Determination of ash content (NF EN ISO 18122). https://viewerbdc.afnor.org/pdf/viewer/CzJnSSTINIM1. Accessed 12 Oct 2021

4. AFNOR (2017) Solid biofuels - Determination of moisture content - Oven dry method - Part 2: Total moisture - Simplified method (NF EN ISO 18134-2). https://viewerbdc.afnor.org/pdf/viewer/VnKCf3Tgsfg1. Accessed 12 Oct 2021

5. AFNOR (2018) Thermal spraying - Qualification testing of thermal sprayers (ISO 14918:2018) (NF EN ISO 14918). https://viewerbdc.afnor.org/pdf/viewer/73kv6TaOnuc1. Accessed 12 Oct 2021 
6. AFNOR (2015b) Solid biofuels - Determination of total content of carbon, hydrogen and nitrogen (NF EN ISO 16948). https://viewerbdc.afnor.org/pdf/viewer/B44OVglz9KU1. Accessed 12 Oct 2021

7. AFNOR (2015c) Solid biofuels - Determination of minor elements (NF EN ISO 16968). https://viewerbdc.afnor.org/pdf/viewer/AyCuwc00x9M1. Accessed 12 Oct 2021

8. Alexander S, Bard D, Barouki R, et al (2017) Dioxines dans l'environnement: quels risques pour la santé? National Institute of Institute of Health and Medical Research (INSERM), Paris France

9. Block C, Van Caneghem J, Van Brecht A, et al (2015) Incineration of Hazardous Waste: A Sustainable Process? Waste Biomass Valorization 6:137-145. https://doi.org/10.1007/s12649-014-9334-3

10. Buekens $A$, Huang $H$ (1998) Comparative evaluation of techniques for controlling the formation and emission of chlorinated dioxins/furans in municipal waste incineration. J Hazard Mater 62:1-33. https://doi.org/10.1016/S0304-3894(98)00153-8

11. Cesprini E, Resente G, Causin V, et al (2020) Energy recovery of glued wood waste - A review. Fuel 262:116520. https://doi.org/10.1016/j.fuel.2019.116520

12. CITEPA / Format SECTEN (2017) Dioxines et furanes - PCDD-F. https://www.citepa.org/fr/air-et-climat/polluants/polluantsorganiques-persistants/dioxines-et-furanes. Accessed 30 Jan 2019

13. CITEPA / Format SECTEN (2019) Citepa_Secten-2019_14_POP.pdf

14. Conesa JA, Font R, Fullana A, et al (2009) Comparison between emissions from the pyrolysis and combustion of different wastes. J Anal Appl Pyrolysis 84:95-102. https://doi.org/10.1016/j.jaap.2008.11.022

15. Cunliffe AM, Williams PT (2009) De-novo formation of dioxins and furans and the memory effect in waste incineration flue gases. Waste Manag 29:739-748. https://doi.org/10.1016/j.wasman.2008.04.004

16. Cunliffe AM, Williams PT (2007a) Desorption of PCDD/PCDF from municipal solid waste incinerator flyash under post-combustion plant conditions. Chemosphere 68:1723-1732. https://doi.org/10.1016/j.chemosphere.2007.03.044

17. Cunliffe AM, Williams PT (2007b) Influence of temperature on PCDD/PCDF desorption from waste incineration flyash under nitrogen. Chemosphere 66:1146-1152. https://doi.org/10.1016/j.chemosphere.2006.06.010

18. Cunliffe AM, Williams PT (2006) Isomeric analysis of PCDD/PCDF in waste incinerator flyash by GC-MS/MS. Chemosphere 62:1846-1855. https://doi.org/10.1016/j.chemosphere.2005.07.011

19. Fängmark I, Strömberg B, Berge N, Rappe C (1994) Influence of small fly ash particles on the post-combustion formation of PCDDs, PCDFs, PCBzs and CPs in a pilot incinerator. Chemosphere 29:1903-1909. https://doi.org/10.1016/0045-6535(94)903557

20. Freire M, Lopes H, Tarelho LAC (2015) Critical aspects of biomass ashes utilization in soils: Composition, leachability, PAH and PCDD/F. Waste Manag 46:304-315. https://doi.org/10.1016/j.wasman.2015.08.036

21. Hagenmaler H, Kraft M, Brunner H, Haag R (1987) Catalytic effects of fly ash from waste incineration facilities on the formation and decomposition of polychlorinated dibenzo-p-dioxins and polychlorinated dibenzofurans. Environ Sci Technol 21:1080-1084. https://doi.org/10.1021/es00164a006

22. Huang $H$, Buekens $A$ (1995) On the mechanisms of dioxin formation in combustion processes. Chemosphere 31:4099-4117. https://doi.org/10.1016/0045-6535(95)80011-9

23. INTERNATIONAL ENERGY AGENCY (2020) Key World Energy Statistics 2020. 81

24. Kakuta Y, Matsuto T, Tanaka N, Masuda T (2005) Influence of residual carbon on the decomposition process of PCDD/Fs in MSWI fly ash. Chemosphere 58:969-975. https://doi.org/10.1016/j.chemosphere.2004.08.086

25. Kakuta Y, Matsuto T, Tojo Y, Tomikawa H (2007) Characterization of residual carbon influencing on de novo synthesis of PCDD/Fs in MSWI fly ash. Chemosphere 68:880-886. https://doi.org/10.1016/j.chemosphere.2007.02.017

26. Lavric ED, Konnov AA, Ruyck JD (2004) Dioxin levels in wood combustion-a review. Biomass Bioenergy 26:115-145. https://doi.org/10.1016/S0961-9534(03)00104-1

27. Li H-W, Wang L-C, Chen C-C, et al (2011) Influence of memory effect caused by aged bag filters on the stack PCDD/F emissions. J Hazard Mater 185:1148-1155. https://doi.org/10.1016/j.jhazmat.2010.10.025

28. Li X, Ma Y, Zhang M, et al (2019) Study on the relationship between waste classification, combustion condition and dioxin emission from waste incineration. Waste Dispos Sustain Energy 1:91-98. https://doi.org/10.1007/s42768-019-00009-9 
29. Liao J, Buekens A, Olie K, et al (2016) Iron and copper catalysis of PCDD/F formation. Environ Sci Pollut Res 23:2415-2425. https://doi.org/10.1007/s11356-015-5437-z

30. Lundin L, Aurell J, Marklund S (2011) The behavior of PCDD and PCDF during thermal treatment of waste incineration ash. Chemosphere 84:305-310. https://doi.org/10.1016/j.chemosphere.2011.04.014

31. Lundin L, Marklund S (2005) Thermal Degradation of PCDD/F in Municipal Solid Waste Ashes in Sealed Glass Ampules. Environ Sci Technol 39:3872-3877. https://doi.org/10.1021/es0485513

32. Martti F (1996) ORGANIC EMISSIONS FROM CO-COMBUSTION OF RDF WITH WOOD CHIPS AND MILLED PEAT IN A BUBBLING PLUIDIZED BED BOILER. 9. https://doi.org/0045-6535(95)00343-6

33. McKay G (2002) Dioxin characterisation, formation and minimisation during municipal solid waste (MSW) incineration: review. Chem Eng J 86:343-368. https://doi.org/10.1016/S1385-8947(01)00228-5

34. Ministry of ecological transition (2020) Biomass energy. Ministry of ecological transition 2020. In: Ministère Transit. Écologique. https://www.ecologie.gouv.fr/biomasse-energie. Accessed 13 Sep 2021

35. Moreno Al, Font R, Conesa JA (2016) Characterization of gaseous emissions and ashes from the combustion of furniture waste. Waste Manag 58:299-308. https://doi.org/10.1016/j.wasman.2016.09.046

36. Nussbaumer T (2010) Overview on Technologies for Biomass Combustion and Emission Levels of Particulate Matter. 78. https://doi.org/ISBN 3-908705-21-5

37. Nussbaumer T, Hasler P (1997) Formation and Reduction of Polychlorinated Dioxins and Furans in Biomass Combustion. In: Bridgwater AV, Boocock DGB (eds) Developments in Thermochemical Biomass Conversion. Springer Netherlands, Dordrecht, pp 1492-1506

38. Phan C, Plouhinec C (2020) Chiffres clés des énergies renouvelables - Édition 2020. France

39. Rules of the Art Grenelle Environnement (2015) Les chaufferies au bois. Programm for professional companies, France

40. Samaras P, Skodras G, Sakellaropoulos GP, Blumenstock M (2001) Toxic emissions during co-combustion of biomass-waste woodlignite blends in an industrial boiler. Chemosphere 43:751-755

41. Schatowitz B, Brandt G, Gafner F, et al (1994) Dioxin emissions from wood combustion. Chemosphere 29:2005-2013. https://doi.org/10.1016/0045-6535(94)90367-0

42. Smołka-Danielowska D, Jabłońska M (2021) Chemical and mineral composition of ashes from wood biomass combustion in domestic wood-fired furnaces. Int J Environ Sci Technol. https://doi.org/10.1007/s13762-021-03506-9

43. Stanmore BR (2004) The formation of dioxins in combustion systems. Combust Flame 136:398-427. https://doi.org/10.1016/j.combustflame.2003.11.004

44. Takasuka G (1995) Thermal decomposition of PCDDsPCDFs in MSW inceneratio fly ash. Fuel Energy Abstr 6:468

45. The european parliament and the council of the european union (2004) DIRECTIVE 2004/107 / EC. https://eur-lex.europa.eu/legalcontent/FR/TXT/HTML/?uri=CELEX:32004L0107. Accessed 29 Sep 2021

46. The european parliament and the council of the european union (2008) Directive 2008/50 / EC of 05/21/08 on ambient air quality and clean air for Europe (AIDA). https://aida.ineris.fr/consultation_document/863. Accessed 13 Sep 2021

47. Trouvé $G$, Delfosse $L$ (1997) Etude bibliographique sur les conditions et mécanismes de formation à basses températures (200 à $400^{\circ} \mathrm{C}$ ) des dibenzodioxines, dibenzofurannes polychlorés. ETUDE $\mathrm{N}^{\circ} 96-02081 \mathrm{~A} 78$

48. Weidemann E, Andersson PL, Bidleman T, et al (2016) 14th congress of combustion by-products and their health effects-origin, fate, and health effects of combustion-related air pollutants in the coming era of bio-based energy sources. Environ Sci Pollut Res 23:8141-8159. https://doi.org/10.1007/s11356-016-6308-y

49. Yang J, Li XD, Meng WJ, et al (2015) Reducing dioxin formation by adding hydrogen in simulated fly ash. Environ Sci Pollut Res 22:13077-13082. https://doi.org/10.1007/s11356-015-4335-8

50. Yokohama N, Otaka H, Minato I, Nakata M (2008) Evaluation of gas-particle partition of dioxins in flue gas I: Evaluation of gasification behavior of polychlorinated dibenzo-p-dioxins and polychlorinated dibenzofurans in fly ash by thermal treatment. J Hazard Mater 153:395-403. https://doi.org/10.1016/j.jhazmat.2007.10.016

51. Zhang L, Su X, Zhang Z, et al (2014) Characterization of fly ash from a circulating fluidized bed incinerator of municipal solid waste. Environ Sci Pollut Res 21:12767-12779. https://doi.org/10.1007/s11356-014-3241-9 
52. Zhang M, Buekens A, Li X (2017) Dioxins from Biomass Combustion: An Overview. Waste Biomass Valorization 8:1-20. https://doi.org/10.1007/s12649-016-9744-5

53. Zhang M, Buekens A, Li X (2018) Characterizing boiler ash from a circulating fluidized bed municipal solid waste incinerator and distribution of PCDD/F and PCB. Environ SciPollut Res 25:22775-22789. https://doi.org/10.1007/s11356-018-2402-7

\section{Figures}
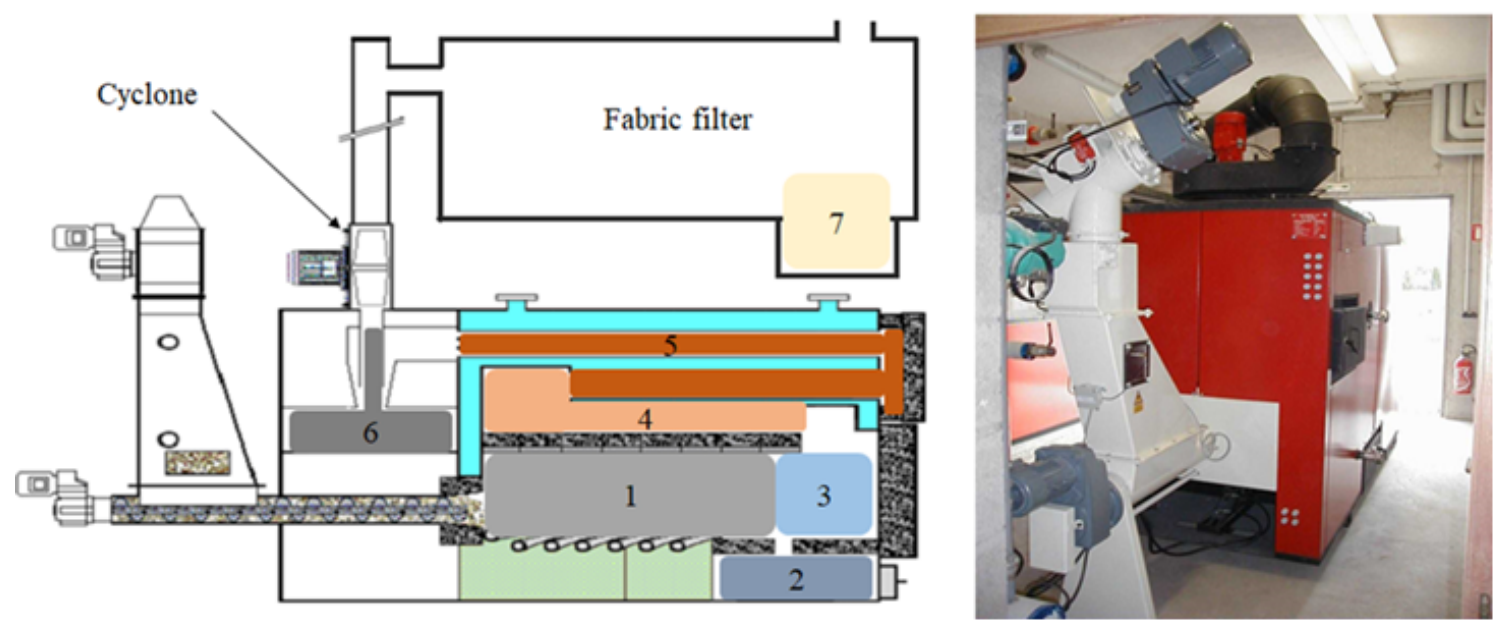

\section{Figure 1}

Photo and schematic Sectional view of the pilot boiler $(200 \mathrm{~kW})$ and ash sampling points :1: ashes from the grate and inner walls of the combustion chamber, 2: ash pan, 3: combustion chamber door and surrounding walls, 4: front exchanger, 5: exchange medium, 6 : cyclone, 7: bag filter, 8: total in fumes.

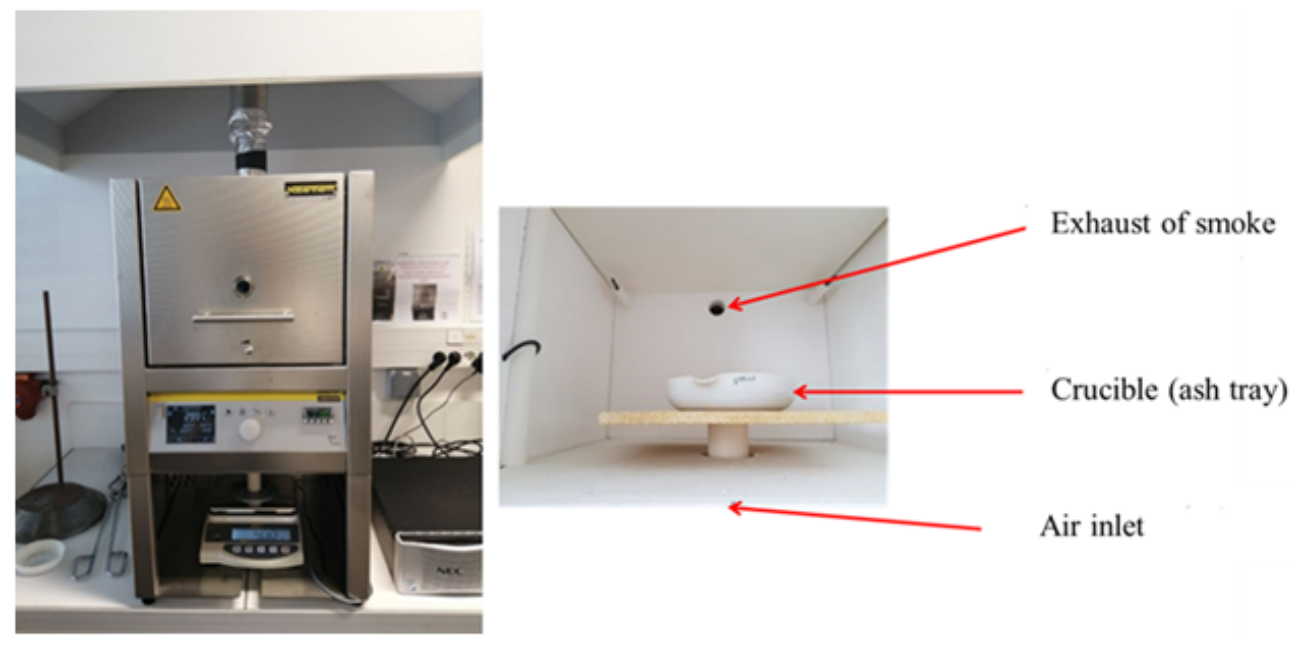

Figure 2

Macro thermogravimetricanalyzer (macro-TGA) (furnaceNabertherm-balance Kern) 


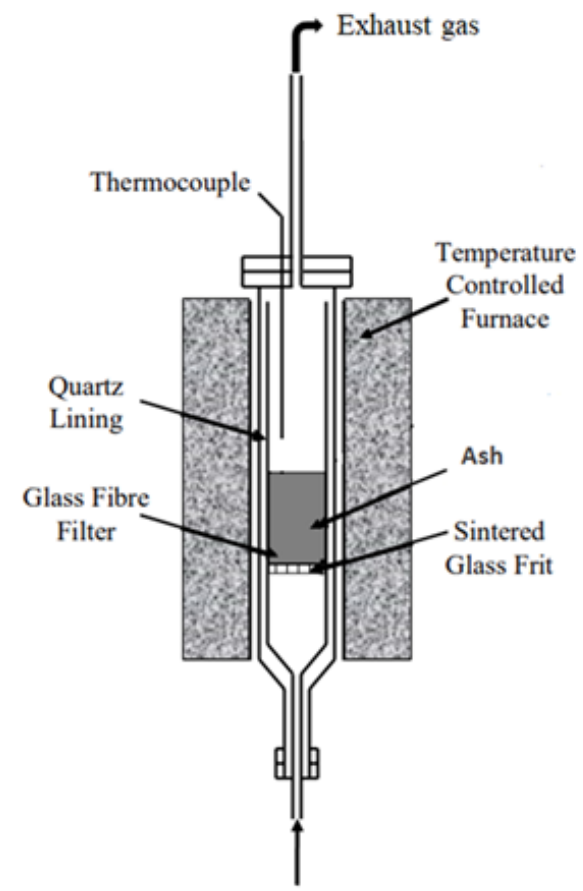

Air inlet

Figure 3

Quartz-lined crossed fixed-bed reactor

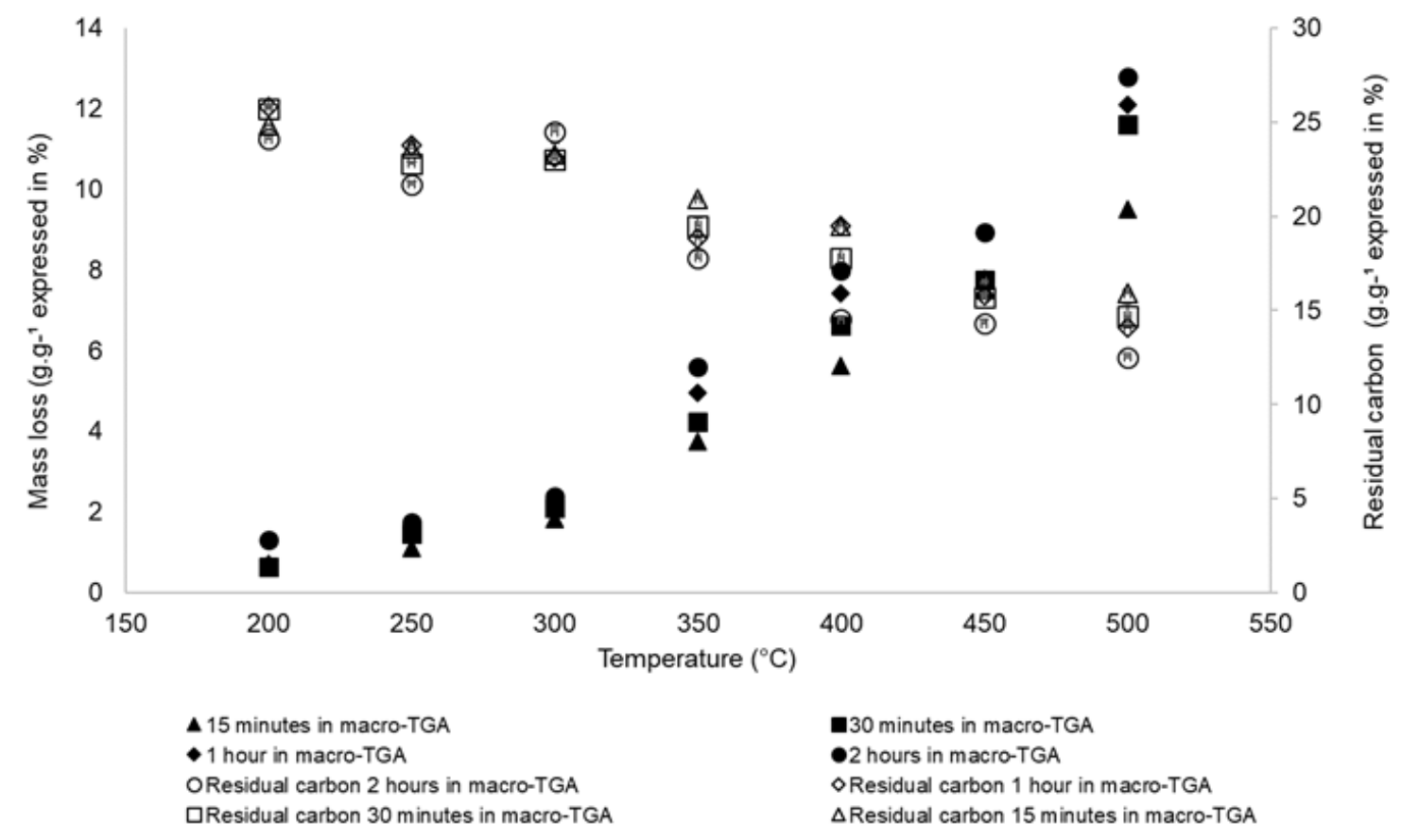

Figure 4

Percentages of mass loss and residual carbon as a function of period and temperature treatment in macro-TGA treated ashes 


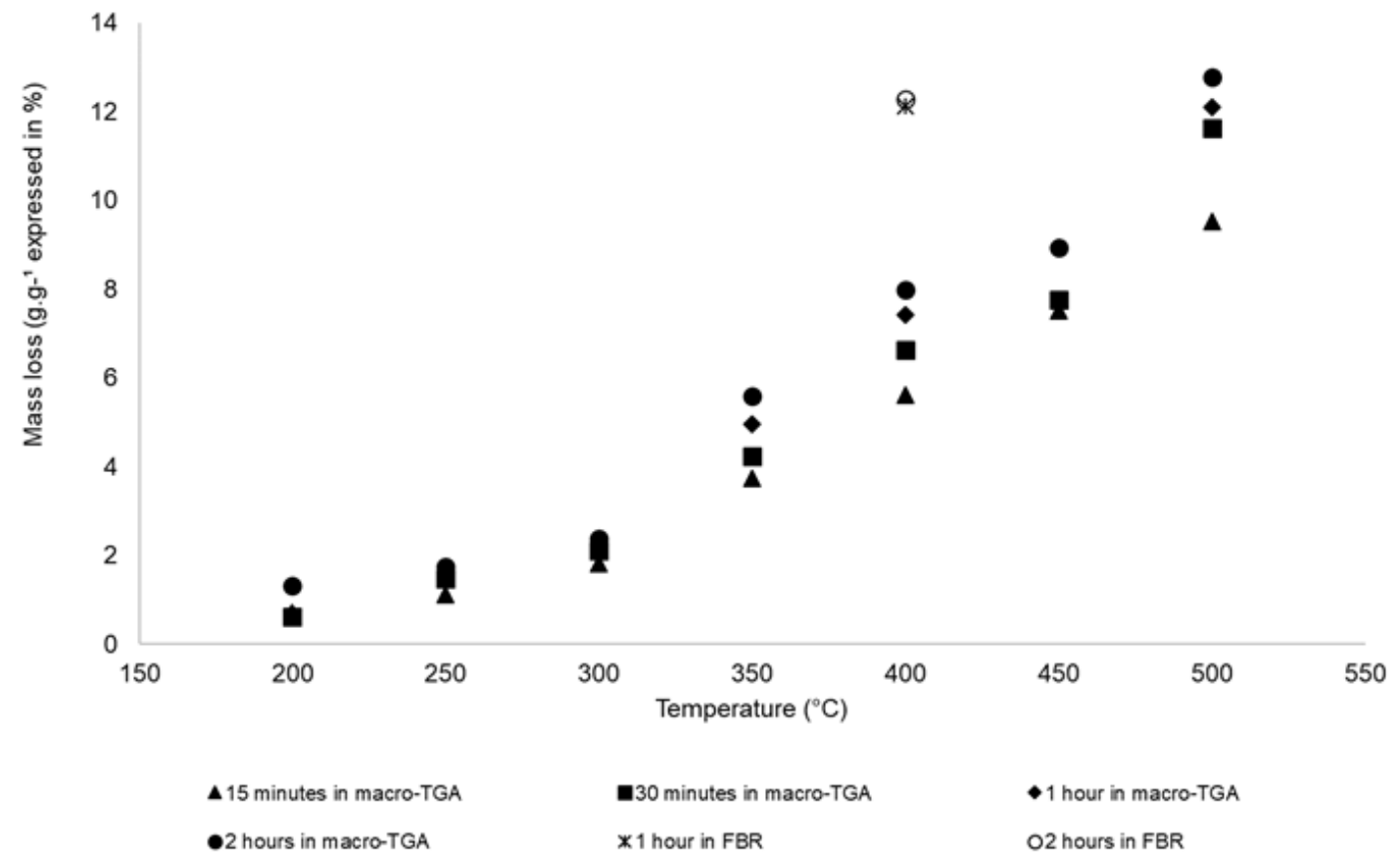

\section{Figure 5}

Percentages of mass loss as a function of period and temperature treatment

in macro-TGA and crossed fixed-bed reactor

\section{Supplementary Files}

This is a list of supplementary files associated with this preprint. Click to download.

- SupplementarymaterialsBARAKET.docx 